\title{
Biosynthesis of the Human C3b/C4b Receptor during Differentiation of the HL-60 Cell Line \\ Identification and Characterization of a Precursor Molecule
}

John P. Atkinson and Elizabeth A. Jones

Howard Hughes Medical Institute Laboratories and Department of Medicine, Division of Rheumatology, Washington University School of Medicine, St. Louis, Missouri 63110

bstract. The $\mathrm{C} 3 \mathrm{~b}$ receptor $(\mathrm{C} 3 \mathrm{bR})$ of the human promyelocytic leukemia cell line (HL-60) was induced by incubating these cells with dimethylsulfoxide (DMSO) or retinoic acid. A majority of differentiated (DMSO- or retinoic acid-treated) but not undifferentiated cells formed rosettes with C3b-coated erythrocytes and were morphologically mature granulocytes. HL-60 cells were surface- or biosynthetically labeled and then solubilized in $1 \%$ Nonidet P-40 in the presence of multiple protease inhibitors. The C3bR was isolated either by immunoprecipitation with anti-C3bR antibodies or by affinity chromatography with hemolytically inactive components in which the internal thioester bond within the $\alpha$-chain was cleaved (iC3)- or iC4-Sepharose. Autoradiographs of $\mathrm{NaDodSO}_{4}$-polyacrylamide gels indicated that the surface-labeled C $3 \mathrm{bR}$ on the differentiated cells had an $M_{\mathrm{r}}$ of 210,000 (nonreduced) or 240,000 (reducing conditions). The bulk $(\sim 85 \%)$ of the radiolabeled material that was isolated from biosynthetically labeled cells co-migrated with the surface-labeled band. A small fraction $(\sim 15 \%)$ of the biosynthetically labeled material that was isolated by affinity chromatography or immunoprecipitation had an $M_{\mathrm{r}}$ of 188,000 , which did not correspond to any surface-labeled band. This putative precursor molecule was characterized by pulse-chase experiments and by analysis of its carbohydrate. In pulse-chase (15-min pulse) studies of differentiated cells, only the $188,000-\mathrm{mol}$ wt molecule was detected at $0 \mathrm{~h}$. By $2 \mathrm{~h},>80 \%$ of counts had chased from the 188,000

This paper was supported in part by Monsanto grant 44217E and CIRID grant 51984.

Received for publication 6 April 1984.

J. Clin. Invest.

(c) The American Society for Clinical Investigation, Inc.

0021-9738/84/11/1649/09 \$1.00

Volume 74, November 1984, 1649-1657 to the 210,000-mol wt molecule. Treatment of these two molecules with endoglycosidases indicated that the 188,000-mol wt molecule possessed high mannose oligosaccharides, while the mature C3bR had complex oligosaccharides. We conclude from these data that the $188,000-\mathrm{mol} \mathrm{wt}$ molecule is a precursor of the C3b receptor of HL-60 cells. Other experiments indicated that the half-maximal time for newly synthesized receptor to attain an $M_{\mathrm{r}}$ of 210,000 was $45 \mathrm{~min}$, and that the $t_{1 / 2}$ for the disappearance of the receptor on the surface of differentiated HL- 60 cells in tissue culture was $\sim 10 \mathrm{~h}$. The ability to observe the induction of the $\mathrm{C} 3 \mathrm{~b}$ receptor as the HL-60 cell line differentiates is an instructive model system to study the biosynthesis of a human integral membrane receptor glycoprotein.

\section{Introduction}

The human $\mathrm{C} 3 \mathrm{~b} / \mathrm{C} 4 \mathrm{~b}$ receptor $\left(\mathrm{C} 3 \mathrm{bR} \mathrm{R}^{1}\right.$ or $\mathrm{CR} 1$ ) is an $\sim 200,000$ mol wt single chain integral membrane glycoprotein found on erythrocytes (E), polymorphonuclear leukocytes (PMN), eosinophils, B lymphocytes, monocytes, and a subpopulation of T lymphocytes (1-3). This molecule has a number of interesting structural and regulatory features (1-7). There are three polymorphic forms of this receptor which are codominantly and sometimes unequally expressed, and there is an $\sim 60,000$ difference in molecular weight among the phenotypes (7).

The functional capabilities of C3bR have been extensively studied $(1,2)$. Rosette assays and affinity chromatography with $\mathrm{C} 3 \mathrm{~b}$ or $\mathrm{C} 4 \mathrm{~b}$ have shown that $\mathrm{C} 3 \mathrm{bR}$ binds both $\mathrm{C} 3 \mathrm{~b}$ and $\mathrm{C} 4 \mathrm{~b}$.

1. Abbreviations used in this paper: DMSO, dimethylsulfoxide; E, erythrocyte; iC 3 and $\mathrm{iC} 4$, hemolytically inactive components in which the internal thioester bond within the $\alpha$-chain has been cleaved; HL-60, human promyelocytic leukemic cell line; C3bR or CR1, $\sim 210,000$-mol wt receptor for C3b and C4b; NP-40, Nonidet P-40; $\mathrm{PMN}$, polymorphonuclear leukocyte; pro-C $3 \mathrm{bR}$, putative precursor molecule of $\mathrm{C} 3 \mathrm{bR}$ with an $M_{\mathrm{r}}$ of $\sim 188,000$; $\mathrm{NaDodSO}_{4}$-PAGE, sodium dodecyl sulfate polyacrylamide gel electrophoresis. 
On PMN, C3bR mediates adsorptive endocytosis (8) and, interestingly, is $\sim 5,000 \mathrm{~mol}$ wt larger than the molecule on $E$ or mononuclear cells (6). C3bR accelerates the decay of convertases of the classical pathway (indicative of $\mathrm{C} 4 \mathrm{~b}$-binding) (9) and of the alternative pathway (indicative of C3b-binding) (3). C3bR of E, lymphocytes, and probably other peripheral blood cells serves as a cofactor such that bound $\mathrm{C} 3 \mathrm{~b}$ can be proteolytically cleaved by the $\mathrm{C} 3 \mathrm{~b}$ inactivator $(3,10,11)$. Thus, on nonphagocytic cells this protein may play an important role in the processing of immune complexes $(12,13)$.

The human promyelocytic cell line (HL-60), derived from a human promyelocytic leukemia, has been widely used to study the induction of differentiation of human cells (14-21). A number of compounds can induce this cell line to develop into granulocytes (dimethylsulfoxide [DMSO], cyclic nucleotides, retinoic acid) or monocytes (vitamin $D$, phorbol esters). HL-60 cells induced to differentiate with cAMP or vitamin D have been demonstrated to rosette with complement coated erythrocytes $(14,21)$. In this work we demonstrate that the C3bR of HL-60 cells was induced as these cells differentiated into mature granulocytes. During our analysis of this induction phenomenon, an 188,000-mol wt precursor of C3bR was discovered.

\section{Methods}

Tissue culture. The HL-60 cell line (gift of A. Kahn, Washington University School of Dental Medicine, St. Louis, MO) was maintained in RPMI 1640 supplemented with $20 \%$ fetal bovine calf serum (Irvine Scientific, Santa Ana, CA), $4 \mathrm{mM}$ glutamine, $1 \%$ nonessential amino acids, and an antibiotic-antimycotic mixture that consisted of 100 $\mathrm{U} / \mathrm{ml}$ penicillin, $100 \mu \mathrm{g} / \mathrm{ml}$ streptomycin, and $0.25 \mu \mathrm{g} / \mathrm{ml}$ Fungizone (Gibco Laboratories, Grand Island, NY). Cultures were kept in 150$\mathrm{cm}^{2}$ culture flasks (Corning Glass Works, Corning, NY) in a $5 \%$ $\mathrm{CO}_{2} / 95 \%$ air atmosphere at $37^{\circ} \mathrm{C}$. Under these conditions, the generation time was $\sim 22 \mathrm{~h}$ with $>90 \%$ viability.

Differentiation. The HL-60 cells were induced to differentiate along the granulocytic pathway by incubation with $1 \%$ DMSO (Sigma Chemical Co., St. Louis, MO). In other studies, differentiation was induced by $1 \times 10^{-6} \mathrm{M}$ retinoic acid (18) and $1 \times 10^{-7} \mathrm{M}$ vitamin $\mathrm{D}$ (21). Morphologic changes were assessed by examination of Wrightstained cytocentrifuged preparations.

Rosette assay. Sheep E $\left(1 \times 10^{9} / \mathrm{ml}\right)$ were sensitized $(15 \mathrm{~min}$ at $\left.37^{\circ} \mathrm{C}\right)$ with an equal volume of rabbit IgM (1:120 dilution) or hemolysin (1:300) anti-sheep E antibodies (Cordis Corp., Miami, FL). Human serum was diluted (usually 1:100) in veronal-buffered saline and equal volumes of this complement source were incubated with EA $\left(5 \times 10^{8} / \mathrm{ml}\right)$ for $15 \mathrm{~min}$ at $37^{\circ} \mathrm{C}$. EAC were washed and resuspended in veronal-buffered saline. $0.5 \mathrm{ml}$ of EAC $\left(2.5 \times 10^{8} / \mathrm{ml}\right)$ and $0.5 \mathrm{ml}$ of $\mathrm{HL}-60$ cells $\left(2 \times 10^{6} / \mathrm{ml}\right)$ were mixed and centrifuged at $60 \mathrm{~g}$ for $5 \mathrm{~min}$ at $4^{\circ} \mathrm{C}$. After a 30 -min incubation at $37^{\circ} \mathrm{C}$, the cells were gently resuspended with a Pasteur pipette and the proportion of HL-60 cells forming rosettes (two or more attached or ingested E) determined by microscopic examination of $100-200$ cells. To assess inhibition of rosette formation by monoclonal anti-CR 1s, HL-60 cells were incubated for $30 \mathrm{~min}$ at $37^{\circ} \mathrm{C}$ with sufficient antibody to immunoprecipitate $>90 \%$ of CR1 of an equivalent quantity of solubilized cells. The HL-60 cells were then evaluated in the rosette assay.

Surface labeling and solubilization. Leukocytes were prepared for surface iodination by washing three times with phosphate-buffered saline (PBS) (10 mM potassium phosphate, $150 \mathrm{mM} \mathrm{NaCl}, \mathrm{pH} 7.4)$. Using a modified lactoperoxidase method $(4,6), 4 \mathrm{ml}$ of cells at concentrations ranging from $2-5 \times 10^{6}$ cells $/ \mathrm{ml}$ were iodinated with $\sim 300 \mu \mathrm{Ci}{ }^{125} \mathrm{I}$ (New England Nuclear, Boston, MA). After iodination, cells $\left(2-5 \times 10^{6} / \mathrm{ml}\right)$ were solubilized at $4^{\circ} \mathrm{C}$ in PBS, $1 \%$ Nonidet P-40 (NP-40), 2 mM phenylmethylsulfonyl fluoride, 3 mM EDTA, 1 $\mu \mathrm{M}$ pepstatin, and $20 \mathrm{mM}$ iodoacetamide. Insoluble material was separated by centrifugation at $33,000 \mathrm{~g}$ for $20 \mathrm{~min}$ at $4^{\circ} \mathrm{C}$. Supernatants were stored at $-20^{\circ} \mathrm{C}$.

Biosynthetic labeling. Differentiated HL-60 cells, operationally defined as cell populations having been exposed to $1 \%$ DMSO for at least $2 \mathrm{~d}$, were washed twice in methionine-free media and resuspended in the same media to a concentration of $1 \times 10^{6} \mathrm{cells} / \mathrm{ml}$. $\left.{ }^{35} \mathrm{~S}\right]$ methionine $(>1,000 \mathrm{Ci} / \mathrm{mM}$ ) (Amersham Corp., Arlington Heights, IL) was added $\left(10 \mathrm{mCi} / 0.5\right.$ to $1.5 \times 10^{9}$ cells in $\left.500-1,500 \mathrm{ml}\right)$. Incorporation of radioactivity was monitored by removal of $2-\mathrm{ml}$ aliquots, centrifugation, and counting. 20-35\% incorporation was routinely achieved. Viability, assessed by trypan blue exclusion, was $>85 \%$ after $8 \mathrm{~h}$. Cells were then washed and solubilized as described above. In other experiments, after washing, the cells were resuspended in media that contained cold methionine, and then aliquots were solubilized at various times thereafter. For pulse-chase experiments, differentiated HL-60 cells $\left(\sim 1 \times 10^{9}\right.$ cells in $\left.1,000 \mathrm{ml}\right)$ were washed, incubated in serum-free media for $1 \mathrm{~h}$, pulsed for 15 min with $\left[{ }^{35}\right.$ S]methionine, washed in nonradioactive medium, and incubated in fresh medium for the chase period.

Affinity chromatography. iC3, iC4, bovine serum albumin (BSA) or rabbit gamma globulins fraction II (Pentex, Miles Laboratories, Inc., Elkhart, IN) were coupled to cyanogen bromide activated Sepharose-4B (Sigma Chemical Co.) as previously described $(4,6)$. Radiolabeled, solubilized preparations from $2 \times 10^{8} \mathrm{HL}-60$ cells were incubated with $0.4 \mathrm{ml}$ of packed IgG-Sepharose beads with constant mixing for $30 \mathrm{~min}$ at room temperature and then centrifuged at $\mathbf{3 0 0}$ $g$ for $5 \mathrm{~min}$. The supernatant was diluted with two parts distilled water and incubated at room temperature with constant mixing for $90 \mathrm{~min}$ with $0.4 \mathrm{ml} \mathrm{BSA}$-, iC4 or iC3-Sepharose. Samples were then centrifuged at $300 \mathrm{~g}$ for $5 \mathrm{~min}$ and the Sepharose beads transferred to $0.7 \times 4-\mathrm{cm}$ plastic columns (Bio-Rad Laboratories, Richmond, CA) with $6 \mathrm{ml}$ of borate buffer $(65 \mathrm{mM}$ borate, $50 \mathrm{mM} \mathrm{NaCl}, \mathrm{pH} 8.0)$ that contained $1 \% \mathrm{NP}-40$ and $2 \mathrm{mM}$ phenylmethylsulfonyl fluoride. Beads were washed once with $3 \mathrm{ml}$ of borate buffer, $1 \% \mathrm{NP}-40$, and then eluted with four successive $2-\mathrm{ml}$ aliquots of $400 \mathrm{mM} \mathrm{NaCl}, 1 \% \mathrm{NP}-40$. Eluates were then dialyzed against distilled water, lyophilized, and precipitated with acetone to remove NP-40 (4). Samples were then resuspended in $0.08-0.30 \mathrm{ml}$ disintegration buffer $(0.25 \mathrm{M}$ Tris, $\mathrm{pH}$ $6.8,2 \% \mathrm{NaDodSO}_{4}, 10 \%$ glycerin, $0.001 \%$ bromophenol blue) in preparation for $\mathrm{NaDodSO}_{4}$-sodium dodecyl sulfate polyacrylamide gel electrophoresis (PAGE) analysis.

Immunoprecipitation. Ascitic fluid that contained a mouse monoclonal IgG1 antibody (57F) and rabbit polyclonal antibody (R137), both specific for CR1, were generous gifts of Victor Nussenzweig, New York University (9), New York. Solubilized cell preparations from $5 \times 10^{7} \mathrm{HL}-60$ cells were incubated for $1 \mathrm{~h}$ at $4^{\circ} \mathrm{C}$ with $0.025 \mathrm{ml}$ of 1:100 dilution of ascitic fluid of specific mouse monoclonal anti-C $3 \mathrm{bR}$ or a nonspecific mouse antibody of the same subclass, and $0.050 \mathrm{ml}$ 
of 1:10 dilution of rabbit polyclonal anti-C $3 \mathrm{bR}$ or nonspecific rabbit polyclonal antibody. In the precipitations with the monoclonal antibodies, a rabbit anti-mouse IgG was used as a second antibody. The pellet from $0.5 \mathrm{ml}$ of a $10 \%$ suspension of Staphylococcus aureus, (Cowan C3b inactivator strain) was used to bind antibody, and pellets were washed four times at $4^{\circ} \mathrm{C}$ in $1 \mathrm{ml}$ of PBS, $1 \%$ NP-40. Proteins were removed by resuspending the pellet in $0.08 \mathrm{ml}$ of disintegration buffer and heating at $80^{\circ} \mathrm{C}$ for $10 \mathrm{~min}$. The pellet was removed by centrifugation and supernatants analyzed by $\mathrm{NaDodSO}_{4}$-PAGE.

NaDodSO,PAGE. Slab gels were performed according to the method of Laemmli using $5 \%$ or a $6-18 \%$ polyacrylamide gradient $(4$, $6,7)$. Samples were loaded onto a $3 \%$ stacking gel. Samples were reduced with $5 \%$ (vol/vol) 2-mercaptoethanol and heated at $80^{\circ} \mathrm{C}$ for $10 \mathrm{~min}$. Dried gels were exposed to X-Omat AR film (XAR-5, Eastman Kodak Co., Rochester, NY) at $-70^{\circ} \mathrm{C}$. For exposure of $\left[{ }^{35} \mathrm{~S}\right]$ methionine containing autoradiographs, gels were treated with EN $^{3} \mathrm{HANCE}$ (New England Nuclear) before drying. Molecular weights were calibrated with previously reported standards (4).

Treatment of receptor preparations with endoglycosidases. Radiolabeled receptor purified by affinity chromatography was resuspended in $0.10 \mathrm{ml}$ of $50 \mathrm{mM}$ sodium acetate, $0.1 \% \mathrm{SDS}, \mathrm{pH} 5.5$, and heated at $80^{\circ} \mathrm{C}$ for $5 \mathrm{~min}$. After cooling to room temperature, $15 \mathrm{mU}$ of endoglycosidase $H$ (Miles Laboratories) was added and the samples incubated at $37^{\circ} \mathrm{C}$ for $16 \mathrm{~h}$. For endoglycosidase $\mathrm{F}$ (New England Nuclear) treatment, samples were resuspended in $0.1 \mathrm{ml}$ of $50 \mathrm{mM}$ sodium phosphate, 50 mM EDTA, $1.0 \%$ NP-40, 1.0\% NaDodSO 4 , $1 \%$ 2-mercaptoethanol, $\mathrm{pH} 6.1$, and heated at $80^{\circ} \mathrm{C}$ for $5 \mathrm{~min}$. After cooling to room temperature, $100 \mathrm{mU}$ of endoglycosidase $\mathrm{F}$ was added and the sample was incubated for $16 \mathrm{~h}$ at $37^{\circ} \mathrm{C}$. Endoglycosidase-H or $-\mathrm{F}$ treated samples were then precipitated by adding $2.5 \mathrm{ml}$ of $-20^{\circ} \mathrm{C}$

Table I. Analysis of the Presence of the C3bR by Rosette Formation on Undifferentiated and Differentiated HL-60 Cells*

\begin{tabular}{lll}
\hline & \multicolumn{2}{c}{ \% Rosette-positive HL-60 cells } \\
\cline { 2 - 3 } Indicator cells & Undifferentiated & Differentiated \\
\hline E & $<2$ & $<1$ \\
EA§ & 4 & 5 \\
EAC" & 16 & 73 \\
\hline
\end{tabular}

* These data represent the mean of two experiments.

₹ Cells incubated with $1 \%$ DMSO for $4 \mathrm{~d}$. In other experiments, $>60 \%$ of cells formed rosettes after a $2-d$ incubation with $1 \%$ DMSO. $\S$ Sheep $E$ incubated with a subagglutinating quantity of rabbit IgM anti-sheep E. In experiments where rabbit hemolysin was employed as the antibody source, the results were identical.

"EA incubated with 1/100 dilution of human serum. In other experiments, similar results were obtained with $\mathrm{E}$ antibody incubated with a $1 / 200,1 / 400$, or $1 / 800$ dilution of human serum. In three additional experiments employing two monoclonal anti-CR1s, one (57F) that does not inhibit rosette formation and a second (2B6, a gift of John O'Shea and Michael Frank, Laboratory of Clinical Investigation, National Institutes of Health, Bethesda, MD, which was initially selected based on rosette inhibitory activity) were tested. As expected, the former did not alter rosette formation, while the latter inhibited by $>90 \%$ rosette formation by differentiated cells. acetone. After $6 \mathrm{~h}$ at $-20^{\circ} \mathrm{C}$, samples were centrifuged at $3,000 \mathrm{~g}$ for $30 \mathrm{~min}$ and supernatant decanted. The pellet was resuspended in 0.08 $\mathrm{ml}$ of reducing disintegration buffer, heated at $80^{\circ} \mathrm{C}$ for $5 \mathrm{~min}$, and loaded directly on gels. Control samples were processed in an identical fashion as treated samples except that no endoglycosidase was added.

\section{Results}

Acquisition of $C 3 b R$ on differentiated HL-60 cells. Based on previous data indicating that differentiated HL-60 cells formed rosettes with complement-coated erythrocytes $(14,21)$, we examined HL-60 cells for the presence of C3b receptors. Less than $20 \%$ of undifferentiated cells formed rosettes with sensitized erythrocytes (Table I). In contrast, $>70 \%$ of the cells that had been induced to differentiate by exposure to DMSO for $4 \mathrm{~d}$ formed rosettes with $\mathrm{C} 3 \mathrm{~b}$-coated $\mathrm{E}$. This rosette formation was inhibited by a monoclonal anti-CR 1 (Table I).

To analyze the C3-binding proteins on this cell line, undifferentiated and differentiated cells were surface-labeled and then immunoprecipitation or affinity chromatography was used to isolate iC3-binding molecules (Fig. $1 A$ ). From undifferentiated cells, only small quantities of a molecule whose $M_{\mathrm{r}}$ $(210,000)$ was similar to previously recognized C3bR were found. From differentiated cells, much larger quantities of the 210,000-mol wt molecule were precipitated by monoclonal or
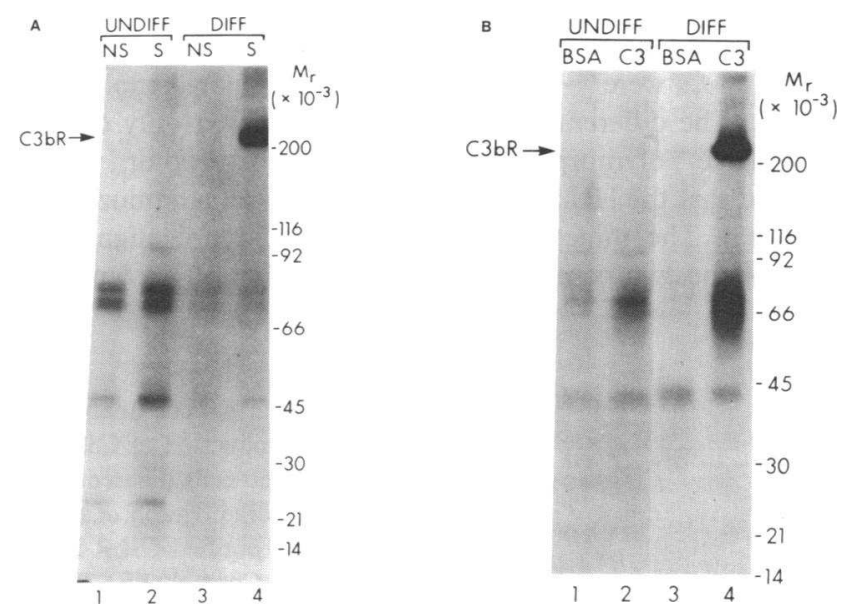

Figure 1. Demonstration of the presence of $\mathrm{C} 3 \mathrm{bR}$ on differentiated (DIFF) HL-60 cells. In both $A$ and $B$, receptor molecules were analyzed by $\mathrm{NaDodSO}_{4}$-PAGE with a $6-18 \%$ gradient slab gel under nonreducing conditions. $(A)$ Autoradiograph of ${ }^{125}$ I-labeled immunoprecipitates from undifferentiated (UNDIFF) (lanes 1 and 2) or DMSO (4 d) differentiated (lanes 3 and 4) HL-60 cells. Aliquot of labeled solubilized cell extracts were immunoprecipitated with nonspecific (NS) monoclonal antibody or specific (S) monoclonal antiC3bR. 2-d exposure. (B) Autoradiograph of ${ }^{125}$ I-labeled C3bR isolated by affinity chromatography. Solubilized preparations from undifferentiated cells were passed over BSA-Sepharose (lane 1) or iC3-Sepharose (lane 2). Lanes 3 and 4 were derived from DMSO (2 d) differentiated cells. 2-d exposure. 
polyclonal anti-C3bR antibodies. This same molecule was isolated from samples at various times after the induction of cell differentiation (see below and Fig. 2) and also from retinoic acid-induced cells (not shown).

C3bR was also isolated by affinity chromatography (Fig. 1 $B)$. A molecule with an $M_{\mathrm{r}}$ of $\sim 210,000$ was barely detectable on undifferentiated cells but again present in relatively large amounts on differentiated cells. This $210,000 \mathrm{~mol} \mathrm{wt} \mathrm{C3bR}$ molecule was also isolated by iC4 affinity chromatography (not shown). The molecule obtained by affinity chromatography aligned with that obtained by immunoprecipitation. Moreover, cross-over experiments in which supernatants were first cleared of receptor by immunoprecipitation and then applied to the affinity column and vice versa indicated that the immunoprecipitation with anti-C3bR or affinity chromatography with iC3-Sepharose removed $>85 \%$ of the receptor in the solubilized preparations derived from differentiated (2-5 d) cell populations.

The samples shown in Fig. 1 were also analyzed under reducing conditions. No differences were observed except for the previously observed $(4,6)$ shift in C3bR mobility to $240,000 \mathrm{~mol} \mathrm{wt}$, which probably reflects cleavage of intrachain disulfide bonds.

The $M_{\mathrm{r}}$ of receptors on differentiated HL-60 cells was compared with that of $\mathrm{CR} 1$ of human $\mathrm{E}$ and PMN (Fig. 3). The individual studied was heterozygous, as his $\mathrm{E}$ expressed both the 190,000 and 220,000-mol wt molecules (4). His PMN also expressed both polymorphic forms of the $\mathrm{C} 3 \mathrm{~b}$ receptor, but their $M_{\mathrm{r}} \mathrm{s}$ were $\sim 5,000$ larger than the related molecules of $E$ (6). The differentiated HL-60 cell expressed only one of the possible polymorphic forms of the $\mathrm{C} 3 \mathrm{~b}$ receptor, which suggested that the HL-60 cells were derived from a homozygous individual. The molecule of HL-60 cells did not align with either of the two common phenotypes. It is not known why

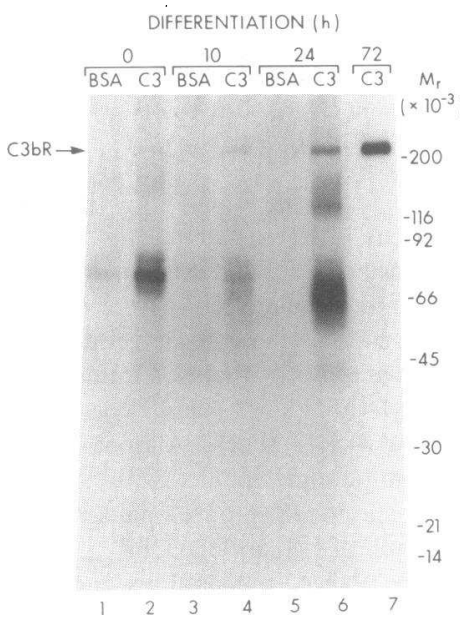

Figure 2. Kinetic analysis of the induction of $\mathrm{C} 3 \mathrm{bR}$ as HL-60 cells differentiate. An autoradiograph of the affinity purified C $3 \mathrm{bR}$ is shown. Control (BSA-Sepharose) lanes are shown for the early time points but were also run at later time points. C3bR was also isolated at 48,72 , and 120 $h$, and the 72-h point is representative of all of these. No other molecules were observed at these later time points (see text for analysis of lower weight molecules isolated at the

earlier time points). For each time point, labeling, solubilization, purification, and gel analysis were performed identically in order to allow quantitation by densitometric scanning. 3.5-d exposure.

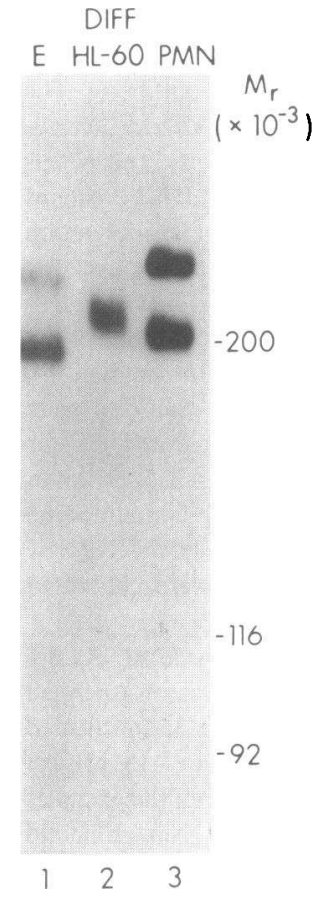

Figure 3. Autoradiographs of ${ }^{125} 1-\mathrm{C} 3 \mathrm{bR}$ isolated from DMSO ( $2 \mathrm{~d})$ differentiated (DIFF) HL-60 cells and normal human peripheral blood E and PMN. C3bR was isolated by immunoprecipitation with a monoclonal anti-C $3 \mathrm{bR}$, and unreduced samples were analyzed on a $5 \% \mathrm{NaDodSO}_{4}$-PAGE. 1.5 d exposure.

the 210,000 band is intermediate in $M_{\mathrm{r}}$. Nevertheless, based on (a) development of increased $\mathrm{C} 3 \mathrm{~b}$-dependent rosette activity upon differentiation and its inhibition by a monoclonal antiCR1, (b) similarity in electrophoretic mobility (under both reducing and nonreducing conditions) to previously identified C3bR molecules, and $(c)$ isolation of the same molecule by immunoprecipitation or affinity chromatography, we concluded that this $210,000-\mathrm{mol} w t$ protein is the C3bR (CR1) of the HL-60 cells.

No other molecule was specifically isolated with immunoprecipitation procedures (Fig. $1 A$ ). However, by iC3 affinity chromatography, a diffuse band with an $M_{\mathrm{r}}$ between 55,000 and 75,000 was also isolated (Fig. $1 B$, track 4) (see below).

Kinetics of receptor acquisition. The kinetics of the acquisition of C3bR on the cell membrane was analyzed by differentiating the cells with DMSO. At various times for up to 5 d, equal numbers of cells were removed, washed, surfacelabeled with ${ }^{125} \mathrm{I}$, and the receptor was purified by affinity chromatography. These receptor preparations were analyzed by $\mathrm{NaDodSO}_{4}-\mathrm{PAGE}$, and the band density on autoradiographs prepared from these gels quantitated by densitometric scanning. During the first $48 \mathrm{~h}$ there was a progressive increase in the quantity of $\mathrm{C} 3 \mathrm{bR}$ (Fig. 2, Table II). In the experiment shown in Fig. 2 (also experiment 1 of Table II), receptor density increased during the entire study. In other experiments, receptor density was maximal by $48 \mathrm{~h}$ and remained the same or decreased by up to $50 \%$ at later time points. In these types of experiments we can not completely rule out the possibility that more efficient labeling of the receptor on the differentiated cells accounts for some of these changes. However, the preceding 
Table II. Quantitation of the Kinetics of the Induction of C3b Receptor on the HL-60 Cell Line*

\begin{tabular}{ccc}
\hline & \multicolumn{2}{c}{ Relative density of C3bR } \\
\cline { 2 - 3 } Time $(h)$ & Exp. 1§ & Exp. 2 \\
\hline 0 & 0 & 0 \\
10 & $<1$ & 0 \\
24 & 2 & 3 \\
36 & ND & 60 \\
48 & ND & 200 \\
72 & 20 & 120 \\
120 & 170 & ND \\
\end{tabular}

* $1 \%$ DMSO was employed as the differentiating agent.

‡ Autoradiographs of varying exposure times were scanned with a densitometer in order to establish the linearity of the system. Units represent the relative density for each time point. Exp. 1 and Exp. 2 cannot be compared in absolute terms.

$\S$ Exp. 1 is taken from Fig. 3. ND, not done.

rosette analysis, the similar overall labeling efficiency of the cells at each time point, and similar results with biosynthetically labeled preparations indicate that an increase in receptor density was largely responsible for the increased quantity of $\mathrm{C} 3 \mathrm{bR}$ on differentiated cell populations.

By affinity chromatography, an iC3 binding protein with an $M_{\mathrm{r}}$ of $60,000-70,000$ was also present (see both Figs. $1 B$ and 2). In the experiment shown in Fig. 2 it is most prominent at $\sim 24 \mathrm{~h}$ after induction but is also present at later time points (Fig. $1 \mathrm{~B}$, track 6). Monoclonal or polyclonal antibodies to C3bR did not immunoprecipitate this molecule (Figs. $1 \mathrm{~A}$ and 3). This $60,000-70,000-$ mol wt molecule is not isolated by C3d affinity chromatography (G. Housley and J. Atkinson, unpublished observations), nor does it have an $M_{\mathrm{r}}$ similar to the C3d receptor (22). It is probably related to similar sized molecule found on human peripheral blood leukocytes (23). Rabbit alveolar macrophages also possess a C3-binding protein with an $M_{\mathrm{r}}$ of $\sim 65,000$ (24).

The band at $72,000 \mathrm{~mol}$ wt at $0 \mathrm{~h}$ appeared to be specific for iC3 (see Fig. $1 B$ as well), but did not align with the more diffuse band that is prominent in this region at $24 \mathrm{~h}$. Since undifferentiated cells rosette poorly if at all, since this material was also present in the BSA control, and since a sharp band with an $M_{\mathrm{r}}$ of 72,000 was not present on differentiated cells, we do not believe it is a specific iC3-binding molecule. Further studies on $\mathrm{C} 3$ binding molecules of this $M_{\mathrm{r}}$ are necessary to better characterize specificity and relationship to CR1.

Biosynthetic-labeling of the receptor. Employing DMSO as the inducing agent, HL-60 cells were allowed to differentiate for $48 \mathrm{~h}$. The cell population was then divided into two aliquots. In one case, cells were radiolabeled with $\left[{ }^{35} \mathrm{~S}\right]-$ methionine for $8 \mathrm{~h}$. In the other, cells were incubated for $8 \mathrm{~h}$ in media and then surface labeled with ${ }^{125} \mathrm{I}$. While the major receptor band isolated from the biosynthetically labeled cells aligned with $\mathrm{C} 3 \mathrm{bR}$ of ${ }^{125} \mathrm{I}$-labeled preparations, an additional band was present on the fluorograph of the biosynthetically derived material (Fig. 4). By densitometric scanning, this molecule constitutes $\sim 15 \%$ of the total counts in the two bands. It has an $M_{\mathrm{r}}$ of $\sim 188,000$ and is purified by both affinity chromatography (Fig. 4) or immunoprecipitation (Fig. $5 A$ ). It is not present on undifferentiated cells. Finally, as with the 210,000 mol wt C3bR of HL-60 cells, it migrated $\sim 30,000$ mol wt higher under reducing conditions (not shown). Therefore, these data indicate that this molecule binds specifically to $\mathrm{iC} 3$, possesses antigenic cross-reactivity with $\mathrm{C} 3 \mathrm{bR}$, behaves similarly to $\mathrm{C} 3 \mathrm{bR}$ under reducing conditions, and is presumably an intracellular molecule since it is not labeled by surface iodination. We therefore tentatively designate this molecule as pro-C $3 \mathrm{bR}$. The identity of the prominent band in lanes 2 and 3 with an $M_{\mathrm{r}}$ of $\sim 75,000$ is unknown (see above).

Pulse-chase analysis of the $C 3 b$ receptor. To further characterize the putative pro-C $3 \mathrm{bR}$, two types of experiments were performed. In the first set of experiments, differentiated cells were pulsed for $15 \mathrm{~min}$ with $\left[{ }^{35} \mathrm{~S}\right]$ methionine, radioactivity was "chased" for up to $8 \mathrm{~h}$, and at multiple time points the solubilized preparation was subjected to immunoprecipitation (Fig. 5) or affinity chromatography. At 0 time the counts were almost entirely localized to the lower $M_{\mathrm{r}}$ molecule (Fig. $5 \mathrm{~A}$ ). Counts chased from the lower to the higher $M_{\mathrm{r}}$ band. Densitometric scanning of these and other autoradiographs indicated that by $60 \mathrm{~min}$ most of the counts had chased into the $210,000-\mathrm{mol} w \mathrm{wt}$ molecule. The $t_{1 / 2}$ for newly synthesized receptor to achieve an $M_{\mathrm{r}}$ equal to that of the surface-labeled

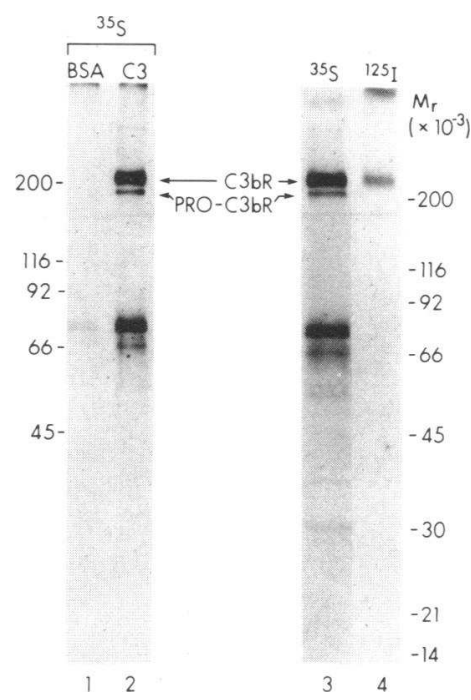

Figure 4. Comparison of surface-labeled and biosynthetically labeled C3bR of DMSO (2 d) differentiated HL-60 cells. Autoradiographs of two 6-18\% gradient slab gels are shown. The HL-60 cells were labeled for $8 \mathrm{~h}$ with ${ }^{35}$ S]methionine. C3bR was isolated by affinity chromatography and then subjected to $\mathrm{NaDodSO}_{4}$ PAGE. 4-d exposure (tracks 1 and 2). The same C3bR preparation shown in tracks 1 and 2 was run on a different gel along with affinity purified ${ }^{125}$ I-labeled HL60 cell preparation that had also been induced for $2 \mathrm{~d}$ with DMSO. The control lane for ${ }^{125} \mathrm{I}$ labeled affinity column purified material is not shown (see Figs. $1 B$ and 3). Longer exposure of this or other gels (Figs. 1-3) containing ${ }^{125}$ I-labeled receptor does not demonstrate a molecule that aligns with the 188,000-mol wt molecule. 4-d exposure (tracks 3 and 4). 


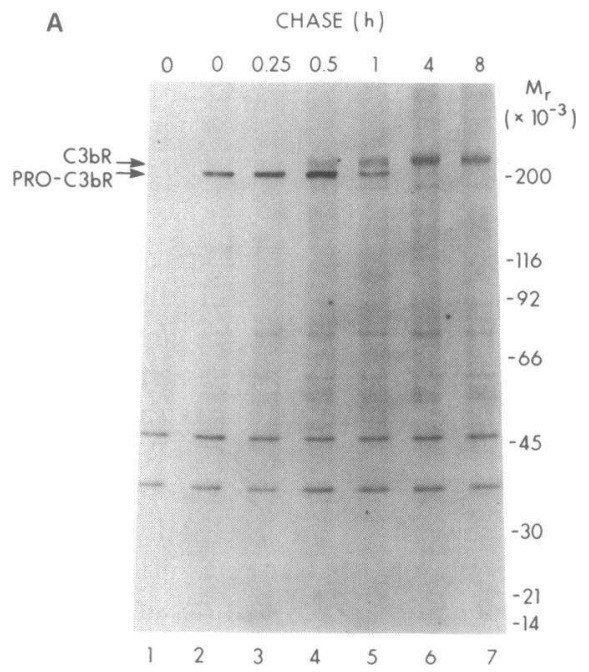

Figure 5. Pulse-chase analysis. $(A)$ Autoradiograph of $\left[{ }^{35}\right.$ S]methionine-labeled receptor. HL-60 cells induced to differentiate for $2 \mathrm{~d}$ with DMSO were pulsed with $\left[{ }^{35} \mathrm{~S}\right]$ methionine for $15 \mathrm{~min}$, washed, incubated in cold medium, and the counts chased for the indicated times. C3bR was purified by immunoprecipitation and analyzed on a $6-18 \%$ gradient gel under nonreducing conditions. Track 1 represents a control immunoprecipitation with a monoclonal antibody of unknown specificity. On this gel the upper band aligned

molecule was $\sim 45 \mathrm{~min}$ (Fig. $5 \mathrm{~B}$ ). Identical results were obtained if the receptor was purified by affinity chromatography (not shown). Although a number of lower molecular weight bands were isolated by immunoprecipitation (Fig. $5 \mathrm{~A}$ ), none of these bands chased into higher molecular weight bands and most were present in the control lane.

In the second type of experiments, differentiated cells were labeled for $6 \mathrm{~h}$ with $\left.{ }^{35} \mathrm{~S}\right] \mathrm{methionine,} \mathrm{washed,} \mathrm{and} \mathrm{then} \mathrm{chased}$ in media that contained nonradiolabeled methionine. By $2 \mathrm{~h}$, most of the counts in the lower molecular weight band had chased into the higher, and by $4 \mathrm{~h}$ no counts remained in the lower band. To determine the $t_{1 / 2}$ of the disappearance of this receptor from the surface of differentiated cells, they were biosynthetically labeled and radioactivity in C3bR followed for $75 \mathrm{~h}$ (Fig. 6). Quantitative analysis of this gel indicated that the $t_{1 / 2}$ for receptor disappearance under these culture conditions was $\sim 10 \mathrm{~h}$.

Pro-C3bR possesses a high mannose oligosaccharide moiety. The formation of $\mathrm{N}$-linked oligosaccharides is initiated cotranslationally and begins by the en bloc transfer of a $\mathrm{Glc}_{3} \mathrm{Man}_{9} \mathrm{GlcNAc}_{2}$ from a lipid carrier to asparagines of nascent polypeptide chains (25-28). Within the Golgi high mannose oligosaccharides are converted to complex oligosaccharides by a series of glycosidases and glycosyltransferases. O-linked sugars are also formed in the Golgi (25-28). After modification in the Golgi, glycoproteins are secreted or, in the case of membrane receptors, transferred to the plasma membrane. While this pathway has been primarily delineated by studying the biosyn- with ${ }^{125}$ I-labeled C3bR from HL-60 cells that were induced for $2 \mathrm{~d}$ with DMSO (not shown). 5-d exposure. (B) Quantitation by densitometric scanning of changes in pro- $C 3 \mathrm{bR}$ and mature $\mathrm{C} 3 \mathrm{bR}$ in the pulse-chase experiment shown in Fig. $5 \mathrm{~A}$. A second experiment, identical to that in Fig. $5 \mathrm{~A}$ except that the receptor was purified by affinity chromatography, was also scanned, and the results were similar. Kontes model 800 fiberoptic scanner (Kontes Scientific, Vineland, $\mathrm{NJ}$ ) in the transmission mode was used to obtain these data.

thesis of secreted proteins, membrane proteins appear to undergo a similar sequence of events $(25-28,29-33)$.

The membrane form of the E CR1 has been shown by others (5) to be decreased by $\sim 10,000$ in molecular weight by treatment with endoglycosidase $F$, an enzyme that removes all

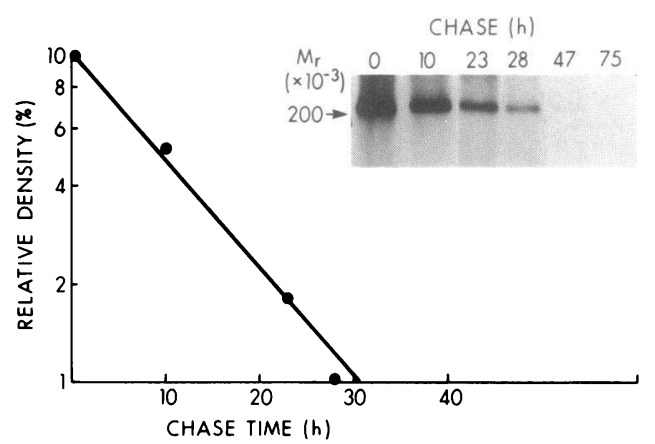

Figure 6. Half-life of C3bR on HL-60 cells in tissue culture. HL-60 cells were labeled with $\left[{ }^{35} \mathrm{~S}\right] \mathrm{methionine}$ for $6 \mathrm{~h}$, washed, resuspended in complete media, and then chased for $75 \mathrm{~h}$. At the time points indicated, an aliquot was removed and the receptor isolated by affinity chromatography and then subjected to $\mathrm{NaDodSO}_{4}(6-18 \%$ gradient) and fluorography. At each time point, affinity chromatography with $\mathrm{iC} 3$ and BSA was performed. No detectable counts corresponding in $M_{\mathrm{r}}$ to $\mathrm{C} 3 \mathrm{bR}$ were isolated from the BSA columns. The fluorograph from which the graph was derived (by densitometric scanning) is shown. Between 1 and $2 \%$ of the labeled receptor remained at $47 \mathrm{~h}$ and $<1 \%$ at $75 \mathrm{~h}$. 
$\mathrm{N}$-linked moieties and therefore both simple and complex sugars (34). We confirmed this result with endoglycosidase $F$ (not shown). Further, the 240,000-mol wt (reducing conditions) C 3 bR of differentiated HL-60 cells was not altered by endoglycosidase $\mathrm{H}$ (Fig. 7), an enzyme that removes high mannose sugars. In contrast, the putative precursor molecule of $\mathrm{C} 3 \mathrm{bR}$ with an $M_{\mathrm{r}}$ of $\sim 188,000$ (pro-C $3 \mathrm{bR}$ ) was reduced in $M_{\mathrm{r}}$ by $\sim 10,000(220,000-210,000)$ by endoglycosidase $\mathrm{H}$ treatment. Parallel treatment of purified human or murine C4 demon-

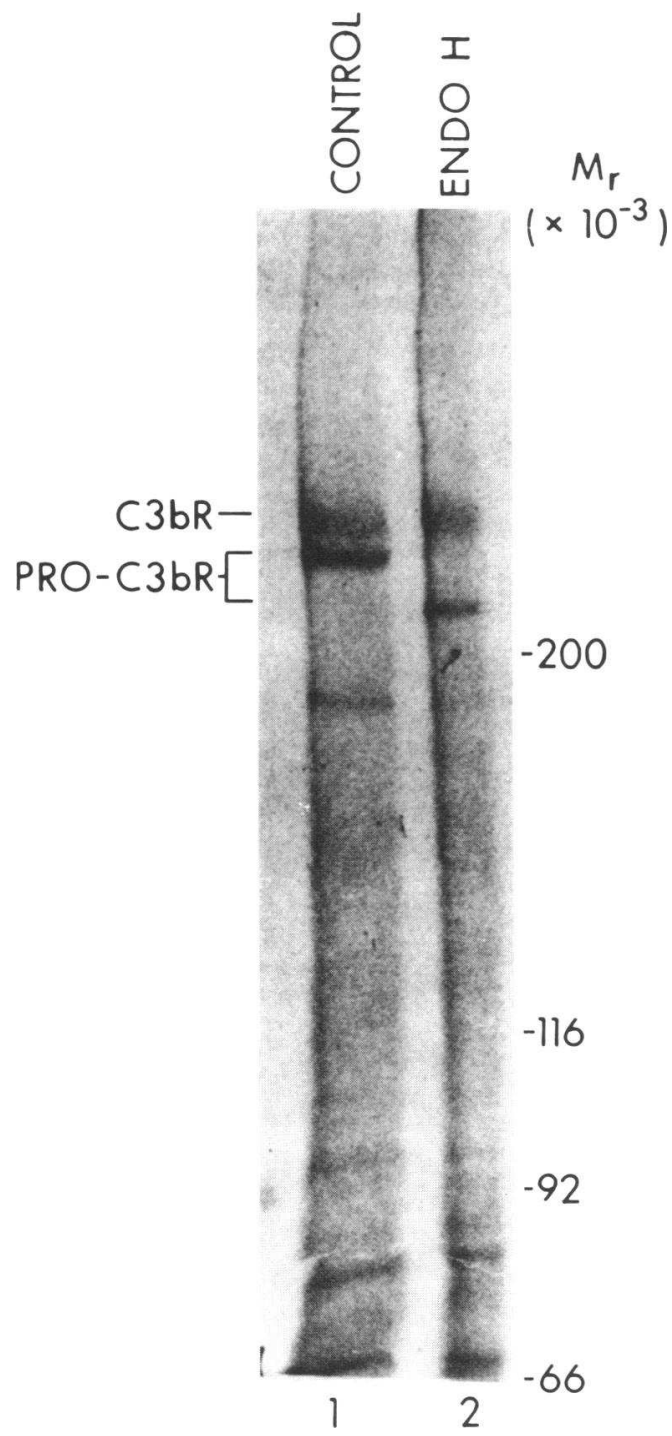

Figure 7. Treatment of pro-C $3 \mathrm{bR}$ and mature $\mathrm{C} 3 \mathrm{bR}$ with endoglycosidase-H (ENDO $\mathrm{H})$. A portion of purified receptor preparation from pulse-chase experiments shown in Fig. 6 (0.5-h time point) was divided into two aliquots. One aliquot was treated with the enzyme for $2 \mathrm{~h}$ at $37^{\circ} \mathrm{C}$. The other aliquot (control) was handled identically except that no enzyme was added. The samples were then run on a $5 \% \mathrm{NaDodSO}_{4}-\mathrm{PAGE}$ under reducing conditions. Autoradiograph, 14-d exposure. strated no evidence of proteolytic activity and removal of the expected (high mannose oligosaccharides on the $\beta$-chain and complex on the $\alpha$-chain) sugar residues by each endoglycosidase (35). These data indicate that the pro-C $3 b R$ possesses high mannose oligosaccharides and that the deglycosylated proC3bR has an $M_{\mathrm{r}}$ of $\sim 210,000$ (reducing) or $\sim 180,000$ (nonreducing conditions).

\section{Discussion}

The differentiation of the HL-60 promyelocytic cell line to relatively mature macrophage-like or neutrophil-like cell populations has been described by many groups (14-21). Induction of this process is mediated by a number of unrelated compounds. Some cells "spontaneously" differentiate (15), probably accounting for the $\mathrm{C} 3 \mathrm{~b}$-dependent rosette activity and for the small quantities of $\mathrm{C} 3 \mathrm{bR}$ isolated from noninduced cells. However, upon differentiation, HL-60 cells synthesize relatively large amounts of $\mathrm{C} 3 \mathrm{bR}$. A small increase in receptor quantity can be seen by $10 \mathrm{~h}$, and the quantity progressively increases up to at least $2 \mathrm{~d}$ and sometimes for $5 \mathrm{~d}$. The magnitude of this increase in receptor density is remarkable (Fig. 2 and Table I). That this molecule is the C $3 \mathrm{bR}$ of these cells is validated by several observations, including the temporal correlation between the development of CR1-dependent rosette activity and increased quantities of $\mathrm{C} 3 \mathrm{bR}$ and, most importantly, purification of a molecule by either immunoprecipitation or affinity chromatography that has a similar electrophoretic mobility to previously identified C3bR.

A comparison by $\mathrm{NaDodSO}_{4}$-PAGE of surface- and biosynthetically labeled receptors led to the discovery of a "second" C3bR with an $M_{\mathrm{r}} 22,000$ less than the major receptor protein that was not isolated from surface-labeled preparations. Its concentration was approximately one-sixth that of the major $\left[{ }^{35}\right.$ S]methionine-labeled receptor. The molecule was purified by iC3 or iC4 affinity columns and was recognized by monoclonal or polyclonal antibodies to C3bR. It "chased" into the mature form of C3bR. Taken together, these data indicate that this molecule is pro-C $3 \mathrm{bR}$.

The pulse-chase experiments demonstrate that $\mathrm{C} 3 \mathrm{bR}$ is rapidly synthesized. After a 15 -min pulse, pro-C3bR was detectable and within the next 30 min a molecule with an $M_{\mathrm{r}}$ identical to the membrane form of $\mathrm{C} 3 \mathrm{bR}$ was present. The majority of pro-C $3 \mathrm{bR}$ chased into the 210,000 -mol wt molecule by $60 \mathrm{~min}$ and the $t_{1 / 2}$ for newly synthesized receptor to reach this $M_{\mathrm{r}}$ was $\sim 45 \mathrm{~min}$. Although we can not be certain that the $210,000-\mathrm{mol} \mathrm{wt}$ form is the same as the membrane form, it is likely, since molecules with intermediate $M_{\mathrm{r}} \mathrm{s}$ were not identified and the ${ }^{125} \mathrm{I}$ - and ${ }^{35} \mathrm{~S}$-labeled $\mathrm{C} 3 \mathrm{bR}$ aligned on $5 \%$, or $6-18 \%$ gradient nonreduced or reduced gels.

Based on these studies and that of others (5), the 210,000mol wt receptor possesses $\mathrm{N}$-linked complex oligosaccharides and contains no high mannose units. This has been demonstrated by showing that there is a decrease in $M_{\mathrm{r}}$ of $\sim 10,000$ 
upon treatment with endoglycosidase $F$ (5, this report), but no shift in $M_{\mathrm{r}}$ with endoglycosidase $\mathrm{H}$ (Fig. 7). While endoglycosidase $\mathrm{H}$ has no effect on $M_{\mathrm{r}}$ of the $210,000-\mathrm{mol}$ wt receptor, it does decrease the $M_{\mathrm{r}}$ of pro-C3bR by $\sim 15,000$, which indicates that pro- $\mathrm{C} 3 \mathrm{bR}$ contains high mannose sugar moieties. In the Golgi complex, high mannose oligosaccharides may be further processed by the removal of the outer glucose and several mannose residues (25-28). Pro-C $3 b R$ is presumably, therefore, in a cell compartment proximal to the mannose processing enzymes of the cis-Golgi. The greater heterogeneity of the ${ }^{35}$ S-labeled $210,000-\mathrm{mol}$ wt C3bR compared with pro$\mathrm{C} 3 \mathrm{bR}$ (Fig. $5 \mathrm{~A}$ ) is possibly due to variations in the complex sugars, such as in the sialic acid content (22). A more detailed analysis of the carbohydrate structure and processing will be presented elsewhere, and the data are entirely consistent with the formulation discussed above.

The pulse-chase analysis indicates that pro-C $3 \mathrm{bR}$ has an $M_{\mathrm{r}}$ of 188,000 (nonreducing conditions) and, as outlined above, possesses high mannose units. Upon removal of the high mannose oligosaccharides of pro-C $3 \mathrm{bR}$ with endoglycosidase $\mathrm{H}$, the $M_{\mathrm{r}}$ is $\sim 180,000$ (nonreducing) or $\sim 210,000$ (reducing conditions). Identification of this molecule as the deglycosylated form of pro-C3bR is of interest. C3bR of human peripheral cells is polymorphic, and the polymorphism is unusual because the $M_{\mathrm{r}}$ of the three allelic variants on nonreducing $\mathrm{NaDodSO}_{4}$-PAGE is $160,000,190,000$, and 220,000 (7). Although it is unlikely that carbohydrate differences accounted for such a large variation in $M_{\mathrm{r}}$, this possibility has not been formally ruled out. However, the fact that the mature 160,000 allele (7) is smaller than the deglycosylated pro-C3bR $(180,000)$ of the HL-60 cell provides evidence against this hypothesis. O-linked sugars are added in the Golgi complex $(25-28,30)$, and therefore would not be present on pro-C $3 \mathrm{bR}$. Thus, these data suggest that the $M_{\mathrm{r}}$ variability among the three alleles is due to peptide differences. Several interesting genetic mechanisms can be envisioned to account for this polymorphism.

The acquisition of this receptor as the HL-60 cell differentiates provides an excellent model system to analyze the induction, biosynthesis, and processing of a human integral membrane glycoprotein. The general features of the biosynthesis of the human C3bR by HL-60 cells is similar to secreted proteins as well as to a number of recently studied membrane glycoproteins (39), including the receptors for insulin (29), low density lipoproteins (30), transferrin (33), asialoglycoprotein (32), and T cell growth factor (31). C3bR has relatively welldefined opsonic and cofactor functions $(1,2)$. Its natural ligands, $\mathrm{C} 3 \mathrm{~b}$ and $\mathrm{C} 4 \mathrm{~b}$, have been partially characterized structurally and the genes have now been cloned for both molecules (36-38). Monoclonal and polyclonal anti-receptor antibodies are available. Finally, C3bR has several unique features that make it particularly attractive for further study: $(a)$ it is present on a wide variety of peripheral blood cells and in several tissues $(1,2) ;(b)$ among erythrocyte and leukocyte populations, it is structurally and functionally heterogeneous $(1,2,4-8$,
11-13); (c) there are several interesting regulatory features (4, $6,7) ;(d)$ three polymorphic variants have been described and there is an apparent 60,000 difference in $M_{\mathrm{r}}$ among the alleles (4-7); and (e) low numbers of this receptor (40-42) as well as one particular phenotype (7) are associated with systemic lupus erythematosus, and family studies suggest that low receptor number may be genetically regulated (41).

\section{References}

1. Berger, M., T. A. Gaither, and M. M. Frank. 1982. Complement receptors. Clin. Immunol. Rev. 1:471-545.

2. Fearon, D. T. 1983. The human C3b receptor. Springer Semin. Immunopath. 6:159-172.

3. Fearon, D. T. 1980. Identification of the membrane glycoprotein that is the $\mathrm{C} 3 \mathrm{~b}$ receptor of the human erythrocyte, polymorphonuclear leukocyte, B lymphocyte, and monocyte. J. Exp. Med. 152:20-30.

4. Dykman, T. R., J. L. Cole, K. Iida, and J. P. Atkinson. 1983. Polymorphism of human erythrocyte $\mathrm{C} 3 \mathrm{~b} / \mathrm{C} 4 \mathrm{~b}$ receptor. Proc. Natl. Acad. Sci. USA. 80:1698-1702.

5. Wong, W. W., J. G. Wilson, and D. T. Fearon. 1983. Genetic regulation of a structural polymorphism of human $\mathrm{C} 3 \mathrm{~b}$ receptor. $J$. Clin. Invest. 72:685-693.

6. Dykman, T. R., J. L. Cole, K. Iida, and J. P. Atkinson. 1983. Structural heterogeneity of the $\mathrm{C} 3 \mathrm{~b} / \mathrm{C} 4 \mathrm{~b}$ receptor (CR1) on human peripheral blood cells. J. Exp. Med. 157:2160-2165.

7. Dykman, T. R., J. A. Hatch, and J. P. Atkinson. 1983. Polymorphism of the human $\mathrm{C} 3 \mathrm{~b} / \mathrm{C} 4 \mathrm{~b}$ receptor: identification of a third allele and analysis of receptor phenotypes in families and patients with systemic lupus erythematosus. J. Exp. Med. 159:691-704.

8. Fearon, D. T., I. Kaneko, and G. G. Tompson. 1981. Membrane distribution and adsorptive endocytosis by $\mathrm{C} 3 \mathrm{~b}$ receptors on human polymorphonuclear leukocytes. J. Exp. Med. 153:1615-1628.

9. Iida, K., and V. Nussenzweig. 1981. Complement receptor is an inhibitor of the complement cascade. J. Exp. Med. 153:1138-1150.

10. Medof, M. E., G. M. Prince, and C. Mold. 1982. Release of soluble immune complexes from immune adherence receptors on human erythrocytes is mediated by $\mathrm{C} 3 \mathrm{~b}$ inactivator independently of $\beta 1 \mathrm{H}$ and is accompanied by generation of C3c. Proc. Natl. Acad. Sci. USA. 79:5047-5051.

11. Iida, K., and V. Nussenzweig. 1983. Functional properties of membrane-associated complement receptor CR1. J. Immunol. 130:1876-1880.

12. Medof, M. E., and G. M. Prince. 1983. Immune complex alterations occur on the human red blood cell membrane. Immunology. 50:11-18.

13. Medof, M. D., K. Iida, C. Mold, and V. Nussenzweig. 1982. Unique role for the complement receptor CR1 in the degradation of C3b associated with immune complexes. J. Exp. Med. 156:1739-1754.

14. Chaplinski, T. J., and J. E. Niedel. 1982. Cyclic nucleotideinduced maturation of human promyelocytic leukemia cells. J. Clin. Invest. 70:953-964.

15. Collins, S. J., F. W. Ruscetti, R. E. Gallagher, and R. C. Gallo. 1978. Terminal differentiation of human promyelocytic leukemia cells induced by dimethylsulfoxide and other polar compounds. Proc. Natl. Acad. Sci. USA. 75:2458-2462.

16. Gahmberg, C. G., K. Nilsson, and L. C. Andersson. 1979. Specific changes in the surface glycoprotein pattern of human promyelocytic leukemic cell line HL-60 during morphologic and functional differentiation. Proc. Natl. Acad. Sci. USA. 76:4087-4091. 
17. Rovera, G., D. Santoli, and C. Damsky. 1979. Human promyelocytic leukemia cells in culture differentiate into macrophage-like cells when treated with a phorbol diester. Proc. Natl. Acad. Sci. USA. 76:2779-2783.

18. Breitman, T. R., S. E. Selonick, and S. J. Collins. 1980. Induction of differentiation of the human promyelocytic leukemia cell line (HL-60) by retinoic acid. Proc. Natl. Acad. Sci. USA. 77:29362940.

19. Mulder, A., S. Alexander, C. P. Engelfriet, A. E. G. Von Dem Borne, Jr., and J. L. Strominger. 1981. Characterization by immunoprecipitation, of myeloid- and monocyte-specific antigens present on the human promyelocytic cell line (HL-60) in three stages of differentiation. Proc. Natl. Acad. Sci. USA. 78:5091-5095.

20. Graziano, R. F., E. D. Ball, and M. W. Fanger. 1983. The expression and modulation of human myeloid-specific antigens during differentiation of the HL-60 cell line. Blood. 61:1215-1221.

21. Bar-Shavit, Z., S. L. Teitelbaum, P. Reitsma, A. Hall, L. E. Pegg, J. Trial, and A. J. Kahn. 1983. Induction of monocytic differentiation and bone resorption by 1,25-dihydroxyvitamin $\mathrm{D}_{3}$. Proc. Natl. Acad. Sci. USA. 80:5907-5911.

22. Iida, K., L. Nadler, and V. Nussenzweig. 1983. Identification of the membrane receptor for the complement fragment $\mathrm{C} 3 \mathrm{~d}$ by means of a monoclonal antibody. J. Exp. Med. 158:1021-1033.

23. Cole, J. L., G. A. Housley, Jr., T. R. Dykman, R. P. MacDermott, and J. P. Atkinson. 1984. Identification of a novel class of C3-binding membrane proteins of human peripheral blood leukocytes and cell lines. Proc. Natl. Acad. Sci. USA. In press.

24. Schneider, R. J., A. Kulczycki, Jr., S. K. Law, and J. P. Atkinson. 1981. Isolation of a biologically active macrophage receptor for the third component of complement. Nature (Lond.). 290:789792.

25. Kornfeld, R., and S. Kornfeld. 1980. Structure of glycoproteins and their oligosaccharide units. In The Biochemistry of Glycoproteins and Proteoglycans. W. Lennarz, editor. Plenum Press, New York. $1-34$

26. Struck, D. K., and W. Lennarz. 1980. The function of saccharide-lipids in synthesis of glycoproteins. In The Biochemistry of Glycoproteins and Proteoglycans. W. Lennarz, editor. Plenum Press, New York. 35-83.

27. Schacter, H., and S. Roseman. 1980. Mammalian glycosyl transferases: their role in the synthesis and function of complex carbohydrates and glycolipids. In The Biochemistry of Glycoproteins and Proteoglycans. W. Lennarz, editor. Plenum Press, New York. 85160.

28. Hubbard, S. C., and R. J. Ivatt. 1981. Synthesis and processing of asparagine-linked oligosaccharides. Annu. Rev. Biochem. 50:555583.

29. Hedo, J. A., C. R. Kahn, M. Hayashi, K. M. Yamada, and M. Kasuga. 1983. Biosynthesis and glycosylation of the insulin receptor.
Evidence for a single polypeptide precursor of the two major subunits. J. Biol. Chem. 258:10020-10026.

30. Cummings, R. D., S. Kornfeld, W. J. Schneider, K. K. Hobgood, H. Tolleshaug, M. S. Brown, and J. L. Goldstein. 1983. Biosynthesis of the $\mathrm{N}$ - and $\mathrm{O}$-linked oligosaccharides of the low density lipoprotein receptor. J. Biol. Chem. 258:15261-15273.

31. Leonard, W. J., J. M. Depper, R. J. Robb, T. A. Waldmann, and W. C. Greene. 1983. Characterization of the human receptor for T cell growth factor (TCGF). Proc. Natl. Acad. Sci. USA. 80:69576961.

32. Schwartz, A., and D. Rupi. 1983. Biosynthesis of the human asialoglycoprotein receptor. J. Biol. Chem. 258:11249-11255.

33. Schneider, C., R. Sutherland, R. Newman, and M. Greaves. 1982. Structural features of the cell surface receptor for transferrin that is recognized by the monoclonal antibody OKT9. J. Biol. Chem. 257:8516-8522.

34. Elder, J. H., and S. Alexander. 1982. Endo- $\beta$-N-acetylglucosaminidase $\mathrm{F}$ : endoglycosidase from flavobacterium meningosepticum that cleaves both high-mannose and complex glycoproteins. Proc. Natl. Acad. Sci. USA. 79:4540-4544.

35. Karp, D. R., J. P. Atkinson, and D. C. Shreffler. 1982. Genetic variation in glycosylation of the fourth component of murine complement: association with hemolytic activity. J. Biol. Chem. 257:73307335.

36. Carroll, M. C., and R. R. Porter. 1983. Cloning of a human complement component C4 gene. Proc. Natl. Acad. Sci. USA. 80:264267.

37. Whitehead, A. S., G. Goldberg, D. E. Woods, A. F. Markham, and H. R. Colten. 1983. Use of a cDNA clone for the fourth component of human complement (C4) for analysis of a genetic deficiency of C4 in guinea pig. Proc. Natl. Acad. Sci. USA. 80:53875391.

38. Fey, G., H. Domdey, K. Wiebauer, A. S. Whitehead, and K. Odink. 1983. Structure and expression of the C3 gene. Springer Semin. Immunopath. 6:119-147.

39. Lodish, H. F., W. Braell, A. L. Schwartz, G. J. A. M. Strous, and A. Zilberstein. 1981. Synthesis and assembly of membrane and organelle proteins. Int. Rev. Cytol. 12:247-307.

40. Miyakawa, Y., A. Yamada, K. Kosaka, F. Tsuda, E. Kosugi, and M. Mayumi. 1981. Defective immune-adherence (C3b) receptor on erythrocytes from patients with systemic lupus erythematosus. Lancet. II:493-497.

41. Wilson, J., W. Wong, P. Schur, and D. Fearon. 1983. Mode of inheritance of decreased $\mathrm{C} 3 \mathrm{~b}$ receptors on erythrocytes of patients with systemic lupus erythematosis. N. Engl. J. Med. 307:981-986.

42. Iida, K., R. Mornaghi, and V. Nussenzweig. 1982. Complement receptor $\left(\mathrm{CR}_{1}\right)$ deficiency in erythrocytes from patients with systemic lupus erythematosis. J. Exp. Med. 155:1427-1438. 